\title{
FACTORS ASSOCIATED WITH PARTICIPATION IN THE NATIONAL HEALTH INSURANCE PROGRAM: A PATH ANALYSIS EVIDENCE FROM KUDUS, CENTRAL JAVA
}

\author{
Anom Dwi Prakoso'), Endang Sutisna Sulaeman²), Arief Suryono ${ }^{3)}$ \\ 1)Masters Program in Public Health, Universitas Sebelas Maret \\ 2)Faculty of Medicne, Universitas Sebelas Maret \\ ${ }^{3}$ Faculty of Law, Universitas Sebelas Maret
}

\begin{abstract}
Background: Government of Republic of Indonesia provides the national health insurance program since January 1st 2014. The payment scheme requires hospitals to provide the service first and then make a claim to BPJS on the service by using the tariff package called Indonesia Case Based Groups (INA CBGs). The purpose of this study was to examine factors associated with participation in the national health insurance program using path analysis model.

Subjects and Method: This was a case control study. The study was conducted at 5 subdistricts in Kudus, Central Java, from September to October 2019. A sample of 200 informal workers was selected by purposive sampling. The dependent variable was participation in national health insurance. The independent variables were education, income, knowledge, perceived susceptibility, perceived seriousness, perceived benefit, family support, selfefficacy, and social environment. The data were collected by questionnaire and analyzed by path analysis run on stata 13 .

Results: Participation in the national health insurance program was directly and positively affected by high perceived susceptibility $(b=2.14 ; 95 \% \mathrm{CI}=-0.09$ to $4.38 ; \mathrm{p}=0.060)$, high perceived seriousness $(\mathrm{b}=4.71 ; 95 \% \mathrm{CI}=2.15$ to $7.28 ; \mathrm{p}<0.001)$, high perceived benefit $(\mathrm{b}=$ $2.45 ; 95 \% \mathrm{CI}=0.07$ to $4.83 ; \mathrm{p}=0.044)$, strong family support $(\mathrm{b}=6.31 ; 95 \% \mathrm{CI}=3.20$ to 9.41 ; $\mathrm{p}<0.001$ ), strong self-efficacy ( $\mathrm{b}=3.55 ; 95 \% \mathrm{CI}=1.02$ to $6.07 ; \mathrm{p}=0.006)$, and supportive social environment $(\mathrm{b}=3.39 ; 95 \% \mathrm{CI}=1.24$ to $5.55 ; \mathrm{p}=0.002)$. Participation in the national health insurance program was indirectly affected by education, income, and knowledge.

Conclusion: Participation in the national health insurance program is directly and positively affected by high perceived susceptibility, high perceived seriousness, high perceived benefit, strong family support, strong self-efficacy, and supportive social environment. Participation in the national health insurance program is indirectly affected by education, income, and knowledge.
\end{abstract}

Keywords: national health insurance, Health Belief Model, Social Cognitive Theory

\section{Correspondence:}

Anom Dwi Prakoso. Masters Program in Public Health, Universitas Sebelas Maret. Jl. Ir. Sutami 36A, Surakarta 57126, Centra Java, Indonesia. Email: anomdwiprakoso@-gmail.com. Mobile: +62895363054393. 